UDC 101.1

DOI: $10.21847 / 1728-9343.2019 .1(159) .157988$

DUBININA VIRA,

Ukrainian Medical Stomatological Academy (Poltava, Ukraine)

e-mail:vera.dubinina777@gmail.com,ORCID0000-0001-8024-9823

\title{
HERMENEUTICS H.-G. GADAMER AS A UNIVERSAL PHILOSOPHY OF UNDERSTANDING
}

Considered the hermeneutic project of H.-G. Gadamer as the final phase of the development of the circle of ideas of the German philological hermeneutics of the XIX-XX century. The philosophy of language and the doctrine of understanding and interpretation are explored in connection with the development of philological ideas within the framework of the phenomenological school. The relationship between Gadamer's position and representatives of various linguistic theories of the early twentieth century is shown. The concept of understanding is presented as a key element of the hermeneutic process. Gadamer's hermeneutics is analyzed in the context of his conservative position and his interpretation of Platonic philosophy. Formation of the circle of ideas that formed the basis of the philosophical hermeneutics of H.-G. Gadamer is an integral part of the notion of the essence of language and understanding of its role in the formation of meaning and the entire spiritual culture of mankind, as well as from the concepts of human personality, its creation and development. Consideration of such issues is fundamental to revealing the real role that the hermeneutic project has played and continues to play in the development of European philosophy. The relevance of the theme chosen is determined by the role that the philosophical project of H.-G. Gadamer plays in the development of contemporary ideas about the importance of humanitarian knowledge and, above all, philosophy in the formation of man as such. Gadamer's philosophical hermeneutics with the passage of time only increases its importance for the development of philosophical discourse, thereby confirming its great euristic potential. As in modern Ukrainian philosophy, the development of the problems of understanding, first of all, understanding of the semantic component of human activity in the most diverse fields - from the sphere of art to political discourse, has become more relevant than ever. But in our day one can observe some limitations in understanding the significance and relevance of the Gadameric heritage, the study of which is often of a formal nature; the thinker himself and his works are referred to as a kind of 'figure of contention', without the necessary reflection and further development.

Key words: hermeneutics; understanding; interpretation; language; semantics; platonism.

Introduction. The development of philosophical hermeneutics in the $20^{\text {th }}$ century exceeded the scope the German philosophy, overcoming a certain philological orientation. From the method that was virtually intended to serve historical-philological and religious discourse, hermeneutics turned into an independent philosophical discipline, which reflects the very essence of metaphysical issues. In the first place, this shift is associated with the development of the phenomenological tradition, and especially with the works of $\mathrm{M}$. Heidegger, who managed to discharge hermeneutics from the excessive influence of theories of language and turn it into the basis of a metaphysical inquiry. This, of course, does not mean that the language itself was condemned to philosophical oblivion; it is only about changing the emphasis and research paradigm

At the same time, the development of hermeneutics continued within the philological discourse, resulting in a certain separation from metaphysics and the criticism from linguists. In these studies, the development of hermeneutic problems unfolded against the background of the emer- gence of structuralist theory and methodology, as well as the philosophy of the language of the School of Brentano (Marty, 1908: 297). In this process, the works of A. Marty (1847-1914) (see: Marty, 2004; Marty, 1875; Marty 1908) and H. Steinthal (1823-1899) (Steinthal, 1951; 1871) are especially notable. Thus, a modern researcher of this school R. A. Gromov rates high the scholarly work of A. Marty: "Marty's philosophy of language is an essential moment in the development of linguistics of the $20^{\text {th }}$ century, without which it is hardly possible to present an adequate picture of the transformation of research in this area at the turn of the $19^{\text {th }}$ and $20^{\text {th }}$ centuries. His intentional concept of language as a deliberate (absichtlich) social action; a project of general semantics focused on the communicative theory of meaning; teleological and functional model of language descriptions may be recognized as his original contribution. His ideas were admitted both inside the School of Brentano - they had a significant influence on the development of theories of language and meaning of Husserl, Twardowski, and Meinong - and beyond it" (Gromov, 2004: 107). 
If $\mathrm{A}$. Marty acts as a forerunner of the structuralist and phenomenological method, $\mathrm{H}$. Steinthal extends to the uttermost the understanding of language into the realm of psychological interpretations, thus becoming one of the boldest psychologists in linguistics, as G. G. Shpet explicitly states in his history of hermeneutics (Shpet, 2005: 358).

Thus, hermeneutics as a field of scientific theorizing simultaneously developed in several directions, which by no means contributed to its unified understanding. The image of hermeneutics as a single scientific theory had to take into account all these numerous impulses coming from the phenomenological school, from the philosophy of $\mathrm{M}$. Heidegger and the fundamental ontological issues he placed first, as well as from philological and critical knowledge and experience in reading and interpretation of texts that was accumulated by classical philology.

We believe that this objective was set and solved to a great extent by H.-G. Gadamer, at least if one accepts his theoretical objective about the transcendence of the meaning of the interpreter.

The purpose of the article. In this article, we will consider the works of H.-G. Gadamer in the realm of philosophical hermeneutics, based not only on his fundamental account, "Truth and Method" (Gadamer, 1990; 1988), but also on the comprehension and interpretation of ancient Greek philosophy, in particular, the texts of Plato (Gadamer, 1985; 1991).

Presenting in basic material. H.-G. Gadamer understands philosophical hermeneutics as an important stage in the development of European thought, as an integral part of philosophical reflection, which was prepared by the very logic of the development of philosophy, art, and literature. Therefore, he focuses so much in the work on the analysis and interpretation of the European cultural heritage, which in no way denies, but admits and formalizes other philosophical disciplines: ontology, epistemology, ethics, aesthetics, and others.

Shaping of the set of ideas that formed the basis of philosophical hermeneutics of H.-G. Gadamer is an integral part of the notion of the essence of language and understanding of its role in shaping the meaning and the entire spiritual culture of mankind, as well as the concepts of human personality, its creation and development. Consideration of such issues is fundamental to revealing the actual role that the hermeneutic project has played and continues to play in the development of European philosophy.

The topicality of the subject chosen is determined by the role of the philosophical project of H.-G. Gadamer in the development of modern ideas about the importance of humanitarian knowledge and, above all, philosophy in the shaping of man as such. With the lapse of time, Gadamer's philosophical hermeneutics only increases its importance for the development of philosophical discourse, thereby affirming its great heuristic potential. More than ever, modern Ukrainian philosophy faces the development of the problems of understanding as a pressing issue, first of all, the understanding of the semantic component of human activity in the most diverse fields - from art to political discourse. But today we can observe some limitations in understanding the significance and relevance of Gadamer's heritage, the study of which is often formal; the thinker himself and his works are referred to as a kind of "omission", without the necessary reflection and further development.

German philosophy, due to Heidegger and Husserl, made a very important turn in the $20^{\text {th }}$ century. Quoting Husserl: it was a transition from the world of science to the world of life. It is precisely the perspective from which Gadamer understood hermeneutics. He saw it as the activity of a person or human community, which is related to understanding or interpretation of both the test and what can be perceived as text. Thus, historically philological hermeneutics takes the first place among these activities: if a person did not speak the language and could not understand the texts in this way, a person would not be able to understand everything else.

The traditional subject of hermeneutics is understanding which is the judgment and exploration of semantic horizons presented in text forms. Texts can be written in natural languages, as well as in conventional texts of other arts. Conventionally, the text is any consequence of purposeful human activity - mode of life, architecture, other plastic arts, etc. (Marty, 1875: 95). Gadamer believes that it is hermeneutics which is a way of reading and interpreting texts, and it is precisely the methodology of working with texts that makes it possible to create ways of interpreting all other cultural phenomena.

Gadamer constantly emphasizes that hermeneutics as a humanitarian methodology cannot be a set of rules as in the natural sciences. This is what Kant calls the capacity for judgment. Any scientific methods cannot take this place; there is only one scale of evaluation - the specific accuracy of the agreement, the assurance of semantic reconciliation, which is achieved in the course of practical agreement. Hermeneutics is a specific practice.

The philosopher formulates the special truth of hermeneutics - a truth that cannot be learned and communicated by someone alone. Thus, from the very beginning, hermeneutics acts as a specific correlation of social consciousness, which is expressed in the search for meaning and focused on a common interpretation and understanding. This is the background for Gadamer's understanding of the forms of aesthetic consciousness most fully reflected in the art experience. The philosopher expresses the truth gained by the romantic school that art is a true organon (i.e. a way of acting, an instrument) of philosophy and, apparently, its rival, which surpasses academic philosophy in all senses" (Gadamer, 1977: 256).

In his scientific inquiries, Gadamer always remained a representative of the classical tradition, so it is not surprising that much of his legacy is devoted to the interpretation of ancient Greek philosophy and literature. In this sense, his theoretical objective is very close to the position of M. Heidegger, who "discovered" that we can reproduce the philosophical reflections of the Greeks: "It was possible to learn on the example of Plato and Aristotle because any philosophical thinking is a further reflection of the original experience of the world, that it seeks to conceive with the energy of concepts and contemplations of the language in which we are" (Gadamer, 1977: 258).

From the Gadamer's position, Heidegger creates hermeneutics of factual, self-interpretation of actual human existence. This is the source of Gadamer's hermeneutics: "... the hermeneutic aspect cannot be limited to hermeneutic sciences - art, history, cannot be limited to communication with texts: the universality of the hermeneutic problem, which was already studied by Schleiermacher, belongs to the totality of all intelligent" (Gadamer, 1977: 260).

In his understanding of hermeneutics, as well as the whole philosophy, H.-G. Gadamer acts as a kind of 
conservative innovator who understands very well the specific nature of humanitarian knowledge and the fundamental fact that humanities, by definition, are nonmodern, sophistic. They are more scholastic, but not technical. Here, of course, one can argue, but one cannot deny the philosopher's a deep penetration into the essence of the question. The history of spiritual culture does not coincide with the history of its material, economic or political development. The same applies to the development of natural and mathematical sciences, where the following rule operates - the more modern it is, then the more correct, precise, and true it is. Indeed, ancient mathematics is now taught at high school, and the level of modern physics would be beyond the perception of the ancient world. The development of ancient science is interesting only to its historians and is not relevant for the adoption of modern achievements.

It is completely different, as Gadamer points out, with the study of the spiritual history of mankind, its art, literature, philosophy. Homer is not relevant to any modern application. We read ancient poetry, we study the philosophy of the Greeks, perceiving them as a value in itself, as something that does something with the person itself, and is not used to solve urgent problems. Therefore, Gadamer already explains in the first pages of his main work that the history of philosophy is not a history in a certain sense, but expresses the man's eternal aspiration to the highest spiritual soar, to the highest ideals (Gadamer, 1977: 256-257).

For H.-G. Gadamer, who was consistent in his defence of the ontological aspect of the problem of understanding, hermeneutics is a field of practice. It is implemented as an activity of understanding, for example, as a practice of comprehension of the text. The interpretation of hermeneutics as a study of beingness has the character of a kind of general philosophy of understanding, the subject of which is not only the science of the spirit, but, in general, the totality of knowledge about the world and beingness; and beingness for Gadamer, as for Heidegger, is the time. This perspective influences also the most important premise of Gadamer's hermeneutics: there cannot be any non-historical point of view, from which the researcher could take a look at history as an object of external analysis. Hermeneutic must inevitably move in the circle of historical tradition. Only such an approach allows for penetration into the living material, which is under consideration, guarantees a reduction of the distance between the researcher and the content of spiritual entities.

Gadamer's work on the reconstruction of the meaning of ancient philosophy reflects his conception of understanding, which, like Heidegger's one, is a way of human existence, the problem of conditions and possibilities of understanding should be considered in the area of ontology. This is how Heidegger explores the notion of truth in Plato, which gives us an example of ancient Greek hermeneutics (Heidegger, 1967), which Gadamer uses (Gadamer, 1991).

Gadamer himself provides a very wide interpretation of the hermeneutic phenomenon, in which he sees the integral unity of three aspects - understanding, interpretation, and application. Gadamer states about their inseparability, the actual identity: understanding is always an interpretation and always implies the application of what is to be understood. The concept of Gadamer's application outlines the boundaries of the phenomenon that is to be interpreted, and establishes the fact that all phenomena of spiritual culture shall be understood in a different way in different situations.

In this regard, Gadamer suggests quite original approach to clarifying the meaning and content of education. From his point of view, the essence of education is the return to oneself, the prerequisite of which is alienation. Finding out one's own in unfamiliar is nothing more than a return to oneself from non-being, or from otherness ( $\mathrm{Ga}$ damer, 1988: 56-57).

The fundamental question for any philosophical hermeneutics is the problem of establishing truth in relation to the process of interpretation and its results. Gadamer tries to resolve this problem by referencing to the ancient tradition experience, both philosophical and rhetorical, in

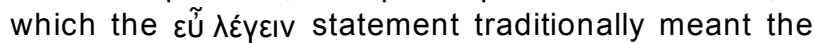
expression of true, correct, and not just the ability to say anything in a good manner (Gadamer, 1988: 56-57). The ancient ideal of eulogy is a model for all attempts to construct a theory of understanding and interpretation, with a pattern based primarily on the natural intuition of man and not subject to any scientific proof.

In general, it is very evident that Gadamer devotes much of his text appealing to the common sense, to sound judgement, which indicates that it is impossible to substantiate the hermeneutic position. The process of interpretation is based on what the philosopher calls "hermeneutic talk" (hermeneutischen Gespräch) (Gadamer, 1988: 461).

In this regard, Gadamer describes the hermeneutic situation that arises only in the process of bringing the individual subjectivity of the interpreter to the historical life: "Thinking can turn to it as the source of this wealth that has been accumulated for by the language itself. That's what Plato does, who relies on the previous logical work done for him by the language itself. This is confirmed by its original history, especially the theory of the formation of concepts in the tradition of the Academy. Thus, we have seen that the demand of Plato to rise above the empirical names implies the fundamental independence of the world of ideas from the language (Heidegger 1967: 88). However, since the rise over names leads to ideas and understands itself as dialectic, that is, it is a contentious point (Heraussehen), common with what is happening and as compatible, a single point (Zusammensehen), which is unique to the species, because it follows the natural direction, followed by the language itself. Rising over the nature of the names only says that the truth of things is not in names. This does not mean that one can dispense with names and logos. Plato has always admitted that it is impossible to do without these intermediaries, although they are not perfect. But it is impossible to know the idea, the true existence of things, other than with the support of such intermediaries. But let's ask ourselves - is there knowledge of the idea as such, in its preciseness and singularity? Is not the essence of things as integral as the whole language itself?" (Gadamer, 1990: 401).

Thus, Gadamer defends a classical and rather conservative position that makes his interpretation of hermeneutics close to Platonism, as well as to a certain rigorism in relation to language. He understands the human language as the language of the mind itself, and the linguistic interpretation as a form of interpretation in general. For this, Gadamer uses a special conceptual series: Deutung; Auslegung; Interpretation; Erläuterung (meaning, explication, interpretation, commentary) (Gadamer, 1990: 402- 
404). In a sense, Gadamer verges towards the concept of the ideal language of Leibniz, although he is far from the analytic and logical rigorism of the latter, since he defends the fundamental metaphorical nature of language consciousness (Gadamer, 1988: 498).

In the view of the above, it is impossible not to mention the criticism of Gadamer's hermeneutic project. In Gadamer's hermeneutics, one may see very easily a conservative desire to rehabilitate tradition, uncritical submission to a certain authority. Also hermeneutics was criticized by the representatives of modern communicative philosophy, in particular, by J. Habermas, in relation to possibility of combining hermeneutic methodology with objective paradigm. The theory of communicative action, which was developed by the latter, takes into account the fact that interpreters are in one way or another involved in social interaction, and therefore they are by no means neutral observers. Habermas treats the understanding is an important moment in the social process that is subject to the public interest.

\section{Conclusions}

The hermeneutic project of H.-G. Gadamer was considered as the final phase of the development of a range of ideas of the German philological hermeneutics of the $19^{\text {th }}$ and $20^{\text {th }}$ centuries. The philosophy of language and the study of understanding and interpretation are examined in connection with the development of hermeneutical ideas within the phenomenological school. The interconnection between Gadamer's position and representatives of various linguistic theories of the early $20^{\text {th }}$ century is shown. The concept of understanding is considered as a key element of the hermeneutic process, and the achievements of H.-G. Gadamer in philosophical hermeneutics were examined based not only on his fundamental work, "Truth and Method", but also on the comprehension and interpretation of ancient Greek philosophy, in particular, the texts of Plato.

Within this article, it is impossible to answer all the critical remarks concerning the philosophical position of the H.-G. Gadamer, however, it should be noted that any social reflection on hermeneutics cannot fully comprise its tasks in the realm of metaphysics, just as the hermeneutic project itself is the final stage in the development of metaphysics. Since Aristotle's time, the latter is understood as the knowledge of the essence of things that cannot be encompassed or transformed into any kind of social discourse. It is precisely this orientation of the Gadamer's philosophical project that makes hermeneutics relatively autonomous from the transient psychological, social and political claims and attempts to use it in favour of one or another public interest.

\section{REFERENCES}

Gadamer, H.-G. (1988). Istina i metod: Osnovy filosofskoy germenevtiki. Transl. from Germ. Moscow: Progress, 704 p. (In Russian)

Gromov, R. A. (2004). Anton Marty. Filosofiya yazyka brentanovskoy shkoly. Predisloviye k publikatsii. Logos, 1 (41): 106137 (In Russian).

Marty, A. (2004). Ob otnoshenii grammatiki i logiki. Transl. from Germ. Logos, 1 (41): 138-168. Retrieved from http:// www.ruthenia.ru/logos/number/41/08.pdf (In Russian).
Shpet, G. G. (2005). Germenevtika i yeye problemy. Mysl i slovo. Izbrannyye trudy. Moscow: ROSSPEN: 248-469. Retrieved from http://old.kpfu.ru/f4/bin_files/40.doc (In Russian).

Gadamer, H.-G. (1977). Kleine Schriften. Ed. 4. Tübingen: 256261 (In German).

Gadamer, H.-G. (1990). Collected Works. Vol. 1. Hermeneutics I. Truth and Method., 494 p. (In German).

Gadamer, H.-G. (1985). Collected Works. Vol. 6. Greek philosophy. Tübingen, J.C. B. Mohr (Paul Siebeck), 341 p. (In German).

Gadamer, H.-G. (1991). Collected Works. Vol. 7. Plato in dialogue. Tübingen, J. C. B. Mohr (Paul Siebeck), 445 p. (In German).

Heidegger, M. (2006). Being And Time. (9 ed.) Tübingen: Max Niemeyer Verlag, 445 p. (In German).

Heidegger, M. (1967). Plato's doctrine of the truth. Frankfurt am Main: Vittorio Klostermann (In German).

Marty, A. (1875). About the origin of the language. Berlin, 192 p. Retrieved from https://archive.org/details/ueberdenursprun00martgoog/page/n8 (In German).

Marty, A. (1908). Investigations on the foundation of the general grammar and philosophy of language. Prague, $345 \mathrm{~s}$. Retrieved from https://archive.org/details/untersuchungenzu01 martuoft/ page/n4 (In German).

Steinthal, H. (1851). The origin of language in connection with the last questions of all knowledge. Berlin. Retrieved from https://archive.org/details/derursprungders00steigoog/page/n12 (In German).

Steinthal, H. (1871). Demolition of linguistics. Vol. I: Introduction to Psychology and Linguistics). Berlin, $362 \mathrm{~s}$. Retrieved from https://books.google.com.ua/books/about/Einleitung_in_die_Psychologie_und_Sprach.html?id=NM7fAAAAMAAJ\&redir_esc=y (In German).

\section{LIST OF REFERENCE LINKS}

Гадамер Х.-Г. Истина и метод: Основы философской герменевтики. Москва: Прогресс, 1988. 704 с.

Громов Р. А. Антон Марти. Философия языка брентановской школы. Предисловие к публикации. Логос. 2004. 1 (41). C. 106-137.

Марти А. Об отношении грамматики и логики. Логос. 2004. 1 (41). C. 138-168.

Шпет Г. Г. Герменевтика и ее проблемы. Шпет Г. Г. Мысль и слово. Избранные труды. Москва: РОССПЭН, 2005. С. 248469. 261.

Gadamer H. G. Kleine Schriften, Bd. 4. Tübingen, 1977. S. 256-

Gadamer H.-G. Gesammelte Werke. Bd. 1. Hermeneutik I. Wahrheit und Methode. Tübingen, 1990. $494 \mathrm{~s}$.

Gadamer H.-G. Gesammelte Werke. Bd. 6. Griechische Philosophie. Tübingen: J. C. B. Mohr (Paul Siebeck), 1985. 341 s.

Gadamer H.-G. Gesammelte Werke. Bd. 7. Plato im Dialog.

Tübingen: J. C. B. Mohr (Paul Siebeck), 1991. 445 s.

Heidegger M. Sein und Zeit. Neunzehnte Auflage. Tübingen: Max Niemeyer Verlag, 2006. $445 \mathrm{~s}$.

Heidegger M. Platons Lehre von der Wahrheit. Frankfurt am Main: Vittorio Klostermann, 1967.

Marty A. Ueber den Ursprung der Sprache. Berlin, 1875. $192 \mathrm{s.}$ Marty A. Untersuchungen zur Grundlegung der allgemeinen Grammatik und Sprachphilosophie. Prague, 1908. $345 \mathrm{~s}$.

Steinthal H. Der Ursprung der Sprache im Zusammenhang mit den Letzten Fragen Alles Wissens. Berlin, 1851.

Steinthal H. Abriss der Sprachwissenschaft. Vol. I: Einleitung in die Psychologie und Sprachwissenschaft). Berlin, 1871. 362 s. 
Дубініна Віра,

Українська медична стоматологічна академія (м. Полтава, Украӥна)

e-mail: vera.dubinina777@gmail.com,ORCID0000-0001-8024-9823

\section{ГЕРМЕНЕВТИКА Г.-Г. ҐАДАМЕРА ЯК УНІВЕРСАЛЬНА ФІЛОСОФІЯ РОЗУМІННЯ}

Формування кола ідей, що лягли в основу філософської герменевтики Г.-ґ. ґадамера, є невід'ємною частиною поняття сутності мови і розуміння їі ролі у формуванні сенсу і всієї духовної культури людства, а також концепцій людської особистості, її створення і розвитку. Філософська герменевтика Ґадамера $з$ часом лише збільшує своє значення в розвитку філософського дискурсу, тим самим підтверджуючи свій великий евристичний потенціал. Як і в сучасній українській філософії, розвиток проблем розуміння, насамперед, розуміння смислової складової людської діяльності в найрізноманітніших сферах - від сфери мистецтва до політичного дискурсу - є сьогодні гостро актуальним. Але в наші дні можна спостерігати певні обмеження в розумінні значущості й актуальності ґадамерівської спадщини, вивчення якої часто має формальний характер. Сам мислитель і його твори згадуються як своєрідна "фігура розбрату", без необхідного відображення і подальшого розвитку. У статті розглядається герменевтичний проект Г.-Ґ. Ґадамера як завершальна фаза розвитку кола ідей німецької філологічної герменевтики XIX-XX ст. Філософрію мови і вчення про розуміння та інтерпретацію досліджено у зв'язку з розвитком герменевтичних ідей в рамках феноменологічної школи. Показано взаємозв'язок позиції ґадамера з представниками різних лінгвістичних теорій початку XX ст. Поняття "розуміння" подано як ключовий елемент герменевтичного процесу. Герменевтика Ґадамера аналізується в контексті консервативної концепції фрілософа і його доробків у царині інтерпретації платонівської фрілософії.

Ключові слова: герменевтика; розуміння; інтерпретація; мова; смисл; платонізм.

\section{Dubinina Vira}

Надійшла до редакції: 11.12.2018

Прийнята до друку: 05.02.2019 